\title{
Perceived Effects of Dietary Behaviour on Household Food Security and Health of the Elderly Yoruba in Oyo State, Nigeria
}

\section{Lukman Tunde Fasasi Ayodele Samuel Jegede}

Department of Sociology University of Ibadan, Ibadan, Nigeria

DOI:10.36108/NJSA/8102/61(0160)

\begin{abstract}
Household Dietary Behaviour (HDB) is concerned with food choices, sharing and serving, and eating patterns adopted in households that ensure access to nutritious food among all members for healthy living. Discriminatory dietary behaviour may limit access to nutritious food, especially by the elderly, and lead to chronic diseases. This study, anchored on Weberian Social Action theory, was a cross-sectional survey of 854 household heads, in five randomly selected Local Government Areas of Oyo state, Nigeria, to examine the perceived effects of changing dietary behaviours on Household Food Security (HFS) and health of the elderly. Data collected were analysed using frequencies and percentages for Univariate analysis, and Chi-square and ANOVA to describe the relationship between HDB, HFS and health of the elderly. Using composite scale, the survey results showed that about $65 \%$ of the elderly in the sampled households were food insecure while analysis of self-reported physical impairments revealed that only about $37 \%$ were healthy. The household dietary behaviours, like food sharing and feeding patterns, significantly related to the HFS, and also the perceived health status of the elderly, at $p<0.05$. There was also significant association between HDB and perceived health status of the elderly. The study concluded that most of the elderly were affected by household dietary behavior, which is inimical to their health. Households should avoid discriminatory practices in food choices and feeding patterns which place the elderly, especially those living alone, at disadvantaged positions.
\end{abstract}

Keywords: Dietary behaviour, feeding patterns, household food security, perceived health status

\section{Introduction}

Families are the cornerstone of all human societies and members naturally expect to find most encouragement, comfort and security, and help when needed (Gurung and Ghimire, 2014). Elderly people are most happy with family life especially, with their children (Läidmäe, Tammsaar, Tulva, and Kasepalu, 2012). The household remains the primary source of food and healthcare for members, and is influenced mainly by people's belief and culture. For the most part, culture and society essentially shape human behaviour, and are viewed as dynamic especially in contemporary period (Hossain and Ali, 2014). The household is a multilevel construct, with cultural 
factors influencing not only food selection and preparation but also intrahousehold allocation of food. Individual dietary intake is the outcome of the intra-household distribution of the available food in the family (Strickhouser, Wright, and Donley, 2014). This may have impact on the household food security and health status of individual members, especially the elderly who are often dependants (Gregorio, Rodriguess, Graca, de Sousa, Dias, Branco and Canhao, 2018).

Food security exists when enough food needed for an active and healthy life is available for all people in the society at all times (Gholami, Rezaei, Askari, Moosavi and Dehghan, 2013). Household food security exists when individuals have stable and sustained access, by socially acceptable means, to adequate amounts of safe and nutritious food for an active, healthy life (PerezEscamilla, 2017). Food insecurity is a pressing social and public health issue, and a major challenge to the well-being of the elderly, in most countries, Nigeria inclusive (Strickhouser, Wright and Donley, 2014). The food security situation has worsened in particular in parts of sub-Saharan Africa, SouthEastern Asia and Western Asia (Food and Agriculture Organisation (FAO), 2017).

Food security is closely related to nutritional security and health (PerezEscamilla, 2017). There is increase in malnutrition resulting from food insecurity (FAO, 2017). The elderly may be food insecure due to limited mobility to available food, or the food may be accessible but not consumed or utilised because of impairments (Ekot, 2013). And this may have negative implication for the realisation of the Sustainable Development Goal of a world without hunger and malnutrition by 2030 (FAO, 2017).

There are many factors that affect the quality and quantity of dietary intake of older adults. There is a relationship between access to adequate intake of quality food, nutritional vulnerability and healthy life of older adult due reduced physical reserve that limits the ability to recover vigorously from an acute health threat or stressor (Starr, McDonald and Bales, 2015). Food is considered essential to the continuity of human existence. Food is now viewed more than for its biological needs but also as a symbol of cultural diversity and social significance. Culture and society significantly influence the dietary intake of individuals and maintains how foods should be categorized (Group, 2016). Food has become a form of identity and most social events are centred on food. Friends and family members tend to influence the eating habits of individuals. Food choices are often determined by ethnic, cultural and religious factors (Lee, 2017). This is largely true of the elderly who depend on household decision making process, which is usually discriminatory discriminated against.

Food insecurity is no longer seen simply as a failure of agriculture to produce sufficient food at the national level, but instead as a failure of livelihoods to guarantee access to sufficient food at the household level. Since food and dietary behaviour are often related to human activities, understanding food beliefs and practices is important to developing dietary programmes 
(Riang'a, Broerse and Nangulu, 2017). Thus deep-rooted food beliefs can affect access to nutritious food. While some cultural beliefs and habits are nutritionally harmful, others are beneficial.

Household food distribution is often related to hierarchical position, with the head of the family and the income-earning members of the household receiving priority in eating. Sometimes intra-household food allocation is based on age differences, but the form differs from setting to setting. These factors lead to changes in consumption pattern which may contribute to the challenge of achieving food security (Lake, Hooper, Abdelhamid, Bemtham, Boxali et al., 2012).

Many household studies on the elderly focused on social and family support. There appear little efforts at understanding the household dietary behaviour that influence access of the elderly to safe and nutritious food for healthy ageing. This study attempted to fill this gap and provide more explanation on behavioural factors that affect dietary intakes and their perceived effects on health of the elderly.

\section{Theory}

The study adopted Webarian Social Action Theory to explain the subjective interpretations that respondents give to food. It was adopted to explain the influence of food beliefs on dietary behaviour in relation to food choice and eating habits of the elderly. It deals with traditional methods of serving and preparing food in the household without significant consideration for the elderly. It was adopted to explain the various factors that influenced different food decisions some of which were based on customs and traditions of the communities about feeding patterns for the elderly. It also explained valuerational decisions in relation to choice of certain foods perceived as capable of enhancing the health status of the elderly. The theory provided explanation for the influence of religion, taste, household disposable income and type of food available in food proscription and prescription on adopted dietary behaviours in the households. It also helped in explaining instrumental rational actions taken in the households on food and health. In this case the household considers the benefits of a dietary behavioural pattern to maximise the nutritional and health benefits of food.

\section{Methods}

\section{Research Design and Study Area}

This study adopted survey design with data obtained across socio-economic strata. The study obtained the perception of the elderly and their caregivers on socio-cultural determinants of feeding patterns and the impacts on the health status of the elderly. The study locations were Five Local Government Areas, LGAs, randomly selected to represent each of the sub-ethnic groups in Oyo State. These were Ibadan North east (Ibadan), Ibarapa Central (Ibarapa), Iseyin (Oke-ogun), Ogbomoso North (Ogbomoso) and Afijio (Oyo). Agriculture is the mainstay of the people. Apart from individual farmstead, there are farm 
settlements owned and coordinated by the State government. The people largely cultivate arable crops like Yam, Cassava and Maize, and cash crops like Cocoa and Oil palm. The state has an average of $6 \%$ population of the elderly which is above the national average of $4 \%$ elderly population.

\section{Study Participants and Inclusion Criteria}

The households selected for the study were those with elderly aged $60+$. Participants were thus heads of households with elderly aged 60 and above, and caregivers. The household heads must have resided in the location for at least two years, be related to the elderly and responsible for household decision making.

\section{Sample Size and Sampling Technique}

Using Leslie Kish (1965) formula 854 household heads were sampled, based on the proportion of the population of the elderly in each LGA. Multi-stage sampling technique was employed to purposively select Oyo state, cluster the state into dialectical groups and randomly select one Local Government Area from each dialectical sub-ethnic group. And through simple random, respondents were sampled from two-fifths of the wards following guidelines from the World Health Organization (WHO) sampling manual (See table 1 for details).

Table 1: Sample Size for Quantitative Data

\begin{tabular}{|l|l|l|r|r|r|r|r|}
\hline S/N & $\begin{array}{l}\text { Local } \\
\text { Government } \\
\text { Areas }\end{array}$ & $\begin{array}{l}\text { Total } \\
\text { Population } \\
\text { Projection } \\
(\mathbf{2 0 1 4 )}\end{array}$ & $\begin{array}{l}\text { Popu- } \\
\text { lation } \\
\text { of } \\
\text { elderly }\end{array}$ & $\boldsymbol{P}$ & $\begin{array}{l}\text { Calculated } \\
\text { Sample } \\
\text { Size }\end{array}$ & $\begin{array}{l}\text { Attrition } \\
\mathbf{( 1 5 \% )}\end{array}$ & $\begin{array}{l}\text { Total } \\
\text { Sample } \\
\text { Size } \\
\text { (N) }\end{array}$ \\
\hline 1. & Ibadan North East & 419,863 & 29,811 & $7.1 \%$ & 158 & 24 & 182 \\
\hline 2. & Ibarapa Central & 147,970 & 9,619 & $6.5 \%$ & 146 & 22 & 168 \\
\hline 3. & Ogbomoso North & 251,733 & 15,104 & $6.0 \%$ & 135 & 20 & 155 \\
\hline 4. & Iseyin & 336,960 & 20,220 & $6.0 \%$ & 135 & 20 & 155 \\
\hline 5. & Afijio & 169,966 & 12,918 & $7.6 \%$ & 169 & 25 & 194 \\
\hline & \multicolumn{7}{|l|}{} \\
\hline
\end{tabular}

Source: NPC, 2014

\section{Research Instruments}

\section{Questionnaire}

Semi-structured questionnaire was administered to heads of households with elderly members. The questionnaire was designed to elicit information about the socio-cultural determinants of household food security status.

\section{Reliability and Validity of Instruments}

The instruments were translated to Yoruba language for ease of administration to those who did not understand English language, and pre-test of instruments was carried out in Ona-ara LGA which shared similar characteristics with study locations. Cronbach's alpha correlation coefficient was used to determine the 
reliability of the instrument.

\section{Data collection Procedure}

Research assistants were engaged and trained to administer questionnaire to participants. The Yoruba language questionnaire was read out to participants but entry was done in the English version for easy analysis. Each respondent was briefed about the purpose of the study, his/her consent was sought and obtained, and thereafter the researcher commenced to administer the questionnaire. Digital recordings of interviews were done by the researcher and the interviewers specially trained on qualitative research techniques. Notes were taken during interviews, and further developed after the interviews. Both the quantitative and qualitative methods of data collection ran simultaneously.

\section{Data Analysis}

Data collected were inputted into a computer and analysed using the Statistical Package for Social Sciences (IBM SPSS version 18). Descriptive statistics was used to explain the socio-demographic characteristics of respondents. Chi square was adopted to test for level of significance in the relationships between household dietary behaviours and household food security. The relationship between feeding patterns and health status of the elderly was also tested. ANOVA was used to determine the degree of influence of the feeding patterns on the health status of the elderly.

\section{Ethical consideration}

Participants were selected based on principle of confidentiality of data, beneficence to participant, Non-Malfeasance to participants and Voluntariness. Approval of the Social sciences and Humanities Ethical Committee of the University of Ibadan, Nigeria, was obtained.

\section{Results}

The study attempted to identify socio-cultural factors that determined food security status of households in the study locations. The demographic information of respondents is presented in table 2: 
Table 2: Distribution of respondents by socio-demographic characteristics

\begin{tabular}{|c|c|c|}
\hline Characteristics & Frequency & Percentage \\
\hline \multicolumn{3}{|l|}{ Gender } \\
\hline Male & 763 & 89.3 \\
\hline Female & 91 & 10.7 \\
\hline \multicolumn{3}{|l|}{ Age in group (in years) } \\
\hline Less than 60 & 174 & 20.4 \\
\hline $60-64$ & 189 & 22.1 \\
\hline $65-69$ & 201 & 23.5 \\
\hline $70-74$ & 122 & 14.3 \\
\hline $75-79$ & 73 & 8.5 \\
\hline $80-84$ & 85 & 10.0 \\
\hline 85 and above & 10 & 1.2 \\
\hline \multicolumn{3}{|l|}{ Marital Status } \\
\hline Single not married & 23 & 2.7 \\
\hline Married but living alone & 37 & 4.3 \\
\hline Married but living together & 639 & 74.8 \\
\hline Widowed & 113 & 13.2 \\
\hline Divorced & 42 & 4.9 \\
\hline \multicolumn{3}{|l|}{ Education level } \\
\hline No formal education & 344 & 40.3 \\
\hline Primary education & 131 & 15.3 \\
\hline Junior / Modern school education & 121 & 14.2 \\
\hline Senior secondary education & 119 & 13.9 \\
\hline Post secondary education & 102 & 11.9 \\
\hline Vocational education & 37 & 4.3 \\
\hline \multicolumn{3}{|l|}{ Occupation } \\
\hline Artisan & 121 & 14.2 \\
\hline Civil servant & 109 & 12.8 \\
\hline Farmer & 265 & 31.0 \\
\hline Trader & 217 & 25.4 \\
\hline Retiree/Pensioner & 90 & 10.5 \\
\hline Cleric/Spiritualist & 25 & 2.9 \\
\hline Unemployed & 27 & 3.2 \\
\hline \multicolumn{3}{|l|}{ Income distribution (monthly) } \\
\hline Less than 10,000 & 224 & 26.2 \\
\hline$\# 10,001-\$ 20,000$ & 251 & 29.4 \\
\hline$\$ 20,001-\$ 30,000$ & 148 & 17.3 \\
\hline$¥ 30,001-\$ 40,000$ & 103 & 12.1 \\
\hline$¥ 40,001-\cong 50,000$ & 63 & 7.4 \\
\hline$¥ 50,001-\cong 60,000$ & 45 & 5.3 \\
\hline$\$ 60,001$ and above & 20 & 2.3 \\
\hline \multicolumn{3}{|l|}{ Other sources of income } \\
\hline$\overline{\text { Donations }}$ & 233 & 27.3 \\
\hline Family support & 462 & 54.1 \\
\hline Government support & 13 & 1.5 \\
\hline NGO support & 30 & 3.5 \\
\hline Cooperatives & 50 & 5.9 \\
\hline Credits from vendors & 64 & 7.5 \\
\hline Other & 2 & 0.2 \\
\hline
\end{tabular}


Table 2 shows that most, $89.3 \%$, of the households were male headed. On age distribution, most, about $80 \%$, respondents were aged 60 . Those $20.4 \%$ that were below 60 years were the caregivers of the elderly who were the heads of the households selected. Most, $74.8 \%$, of the respondents were married and living with their spouses. There was an almost equal religious distribution with $49.4 \%$ respondents being Muslims and $47.2 \%$ as Christians, while $2.0 \%$ of the respondents were traditional worshipers.

About $40 \%$ respondents had no formal education. However, about $73 \%$ of those educated had between primary to secondary school education, while only a few, about $20 \%$ of those educated, had access to post-secondary education. Majority, $86.3 \%$, of the respondents were income earners while $13.2 \%$ respondents were dependents who were pensioners, with irregular payment of pension, and the unemployed (those not actually engaged in any income yielding venture). Those still in active service as civil servants were family relations taking care of the elderly. Respondents' monthly income distribution showed that only about $85 \%$ earned up to $\$ 40,000: 00$ monthly while only about $15 \%$ earned above $\$ 40,000: 00$.

\section{Household Dietary Behaviours, Food Security and Perceived Health Status of the Elderly}

Household Dietary behaviour (HDB) is concerned with food choice, food sharing, food serving and eating patterns adopted in households for the wellbeing of members. The study examined the dietary behaviours adopted in the households to improve and sustain the health status of members, especially the elderly, as presented in Table 3.

Table 3: Relationship between Household Dietary Behaviour and Food Security

\begin{tabular}{|c|c|c|c|c|c|c|c|}
\hline \multirow[t]{2}{*}{ Dietary behaviour } & \multicolumn{3}{|c|}{$\begin{array}{c}\text { Food security status } \\
\end{array}$} & \multirow[b]{2}{*}{ Total } & \multicolumn{3}{|c|}{ Chi square test } \\
\hline & $\begin{array}{lr}\text { Very } r & \text { low } \\
\text { Food } & \text { surety } \\
\text { (with } & \\
\text { hunger) } & \end{array}$ & $\begin{array}{l}\text { Low food } \\
\text { security(wit } \\
\text { hout } \\
\text { hunger }\end{array}$ & Food secure & & $x^{2}$ & $\overline{\mathrm{df}}$ & $\begin{array}{l}\mathrm{p}- \\
\text { value }\end{array}$ \\
\hline \multicolumn{8}{|l|}{$\begin{array}{l}\text { Methods of food } \\
\text { preparation for the } \\
\text { elderly }\end{array}$} \\
\hline Separately & $0(0.0 \%)$ & $8(18.2 \%)$ & $36(81.8 \%)$ & $44(5.2 \%)$ & 188.421 & 4 & 0.000 \\
\hline $\begin{array}{l}\text { Along with other } \\
\text { family members }\end{array}$ & $174(23.4 \%)$ & $374(50.2 \%)$ & $197(26.4 \%)$ & $745(87.2 \%)$ & & & \\
\hline Other forms & $0(0.0 \%)$ & $0(0.0 \%)$ & $65(100.0 \%)$ & $65(7.6 \%)$ & & & \\
\hline \multicolumn{8}{|l|}{$\begin{array}{l}\text { Method of serving } \\
\text { food }\end{array}$} \\
\hline $\begin{array}{l}\text { Household head is } \\
\text { served first }\end{array}$ & $174(30.3 \%)$ & $224(38.9 \%)$ & $177(30.8 \%)$ & $575(67.3 \%)$ & 270.726 & 6 & 0.000 \\
\hline $\begin{array}{l}\text { Income earners are } \\
\text { served first }\end{array}$ & $0(0.0 \%)$ & $104(92.0 \%)$ & $9(8.0 \%)$ & $113(13.2 \%)$ & & & \\
\hline $\begin{array}{l}\text { The children are } \\
\text { served first }\end{array}$ & $0(0.0 \%)$ & $54(48.2)$ & $58(51.8 \%)$ & $112(13.1 \%)$ & & & \\
\hline $\begin{array}{l}\text { The adults are } \\
\text { served first }\end{array}$ & $0(0.0 \%)$ & $0(0.0 \%)$ & $54(100.0 \%)$ & $54(6.3 \%)$ & & & \\
\hline
\end{tabular}




\begin{tabular}{|c|c|c|c|c|c|c|c|}
\hline $\begin{array}{ll}\text { Food } & \text { sharing }\end{array}$ & $88(36.7 \%)$ & $75(31.2 \%)$ & $77(32.1 \%)$ & $240(28.1 \%)$ & 119.120 & 8 & 0.000 \\
\hline methods & $0(0.0 \%)$ & $48(77.4 \%)$ & $14(22.6 \%)$ & $62(7.3 \%)$ & & & \\
\hline According to age & $0(0.0 \%)$ & $31(70.5 \%)$ & $13(29.5 \%)$ & $44(5.2 \%)$ & & & \\
\hline According to gender & $0(0.0 \%)$ & $47(46.1 \%)$ & $55(53.9 \%)$ & $102(11.9 \%)$ & & & \\
\hline \multicolumn{8}{|l|}{ According to roles } \\
\hline $\begin{array}{l}\text { According to } \\
\text { tradition }\end{array}$ & $86(21.2 \%)$ & $181(44.6 \%)$ & $139(34.2 \%)$ & $406(47.5 \%)$ & & & \\
\hline \multicolumn{8}{|l|}{ According to status } \\
\hline \multicolumn{8}{|l|}{$\begin{array}{l}\text { Pattern of eating } \\
\text { the household }\end{array}$} \\
\hline Separately & $174(22.5 \%)$ & $382(49.2 \%)$ & $219(28.3 \%)$ & $775(90.7)$ & 162.421 & 8 & 0.000 \\
\hline $\begin{array}{l}\text { Females alone eat } \\
\text { together }\end{array}$ & $0(0.0 \%)$ & $0(0.0 \%)$ & $25(100.0 \%)$ & $25(2.9 \%)$ & & & \\
\hline $\begin{array}{l}\text { Males alone eat } \\
\text { together }\end{array}$ & $0(0.0 \%)$ & $0(0.0 \%)$ & $11(100.0 \%)$ & $11(1.3 \%)$ & & & \\
\hline $\begin{array}{l}\text { All elderly members } \\
\text { eat together }\end{array}$ & $0(0.0 \%)$ & $0(0.0 \%)$ & $38(100.0 \%)$ & $38(4.4 \%)$ & & & \\
\hline $\begin{array}{l}\text { Everyone eat } \\
\text { together }\end{array}$ & $0(0.0 \%)$ & $0(0.0 \%)$ & $5(100.0 \%)$ & $5(0.6 \%)$ & & & \\
\hline \multicolumn{8}{|l|}{$\begin{array}{l}\text { Determinant of the } \\
\text { type of food served } \\
\text { to the elderly }\end{array}$} \\
\hline Health status & $174(42.2 \%))$ & $109(26.5 \%)$ & $129(31.3 \%)$ & $412(48.2 \%)$ & 278.084 & 8 & 0.000 \\
\hline Accessibility & $0(0.0 \%)$ & $60(56.6 \%)$ & $46(43.4 \%)$ & $106(12.4 \%)$ & & & \\
\hline Availability & $0(0.0 \%)$ & $14(93.3 \%)$ & $1(6.7 \%)$ & $15(1.8 \%)$ & & & \\
\hline Affordability & $0(0.0 \%)$ & $25(100.0 \%)$ & $0(0.0 \%)$ & $25(2.9 \%)$ & & & \\
\hline Tradition & $0(0.0 \%)$ & $174(58.8 \%)$ & $122(41.2 \%)$ & $296(34.7 \%)$ & & & \\
\hline \multicolumn{8}{|l|}{$\begin{array}{ll}\text { Other factors of } \\
\text { food insecurity in } \\
\text { elderly } & \text { in } \\
\text { Household } & \end{array}$} \\
\hline Social Isolation & $171(41.5 \%)$ & $112(27.2 \%)$ & $129(31.3 \%)$ & $412(48.2 \%)$ & 280.321 & 8 & 0.000 \\
\hline $\begin{array}{l}\text { Poor support for } \\
\text { daily activities }\end{array}$ & $3(1.3 \%)$ & $110(48.7 \%)$ & $113(50.0 \%)$ & $226(26.5 \%)$ & & & \\
\hline Poor storage & $0(0.0 \%)$ & $44(67.7 \%)$ & $21(32.3 \%)$ & $65(7.6 \%)$ & & & \\
\hline $\begin{array}{l}\text { Lack of nutritional } \\
\text { information }\end{array}$ & $0(0.0 \%)$ & $26(57.8 \%)$ & $19(42.2 \%)$ & $45(5.3 \%)$ & & & \\
\hline $\begin{array}{l}\text { Poor market } \\
\text { location }\end{array}$ & $0(0.0 \%)$ & $90(84.9 \%)$ & $16(15.1 \%)$ & $106(12.4 \%)$ & & & \\
\hline \multicolumn{8}{|l|}{$\begin{array}{l}\text { Perceived effect of } \\
\text { religion } \\
\text { household } \\
\text { security }\end{array}$} \\
\hline Creates food taboos & $174(42.2 \%)$ & $109(26.4 \%)$ & $129(31.3 \%)$ & $412(48.2 \%)$ & 278.084 & 8 & 0.000 \\
\hline Encourages fasting & $0(0.0 \%)$ & $60(56.6 \%)$ & $46(43.3 \%)$ & $106(12.4 \%)$ & & & \\
\hline $\begin{array}{l}\text { Reduce quality of } \\
\text { food }\end{array}$ & $0(0.0 \%)$ & $14(93.3 \%)$ & $1(6.7 \%)$ & $15(1.8 \%)$ & & & \\
\hline Guides food choices & $0(0.0 \%)$ & $25(100.0 \%)$ & $0(0.0 \%)$ & $25(2.9 \%)$ & & & \\
\hline $\begin{array}{l}\text { No effect on food } \\
\text { status of elderly }\end{array}$ & $0(0.0 \%)$ & $174(58.8 \%)$ & $122(41.2 \%)$ & $296(34.7 \%)$ & & & \\
\hline TOTAL & $174(20.4 \%)$ & $382(44.7 \%)$ & $298(34.9 \%)$ & $854(100.0 \%)$ & & & \\
\hline
\end{tabular}

Table 3 shows that the foods of the elderly were largely prepared along with others, without special consideration for their tastes and preferences, as indicated by $87.2 \%$ of the respondents. This made the elderly to sometimes reject the food prepared. Respondents were asked on pattern of serving food in the households, the results presented in Table 3 further revealed that most, $67.3 \%$, respondents stated that the family heads were often served first. On food sharing practices adopted in the households, the table further shows that most, $47.5 \%$, respondents, stated that food was shared according to the status 
of members in the family, while roles performed in the family influenced food sharing in $5.2 \%$ households.

On how members of the households ate, the results further revealed that in most, 90.7\%, households' members often ate separately. On major determinants of the food served to the elderly in the households, most, $48.2 \%$, respondents considered health status while some, $34.7 \%$, were influenced by religion, custom and tradition, in the choice of food they often served.

On respondents' perceptions about other factors that could predispose the elderly to the challenges of food insecurity, most, $48.2 \%$, respondents felt social isolation could affect the appetite and health status of the elderly. Food stored was based largely on the food beliefs of the people as most, $48.2 \%$, respondents believed that religion often created food taboos.

The study further examined the means adopted by households to maintain and restoring health of the elderly related with household food security. This means related to feeding habits are described as household production of health, and the result presented in table 4:

Table 4: Relationship between Household Food Security and Perceived Health Status of the EIderly

\begin{tabular}{|c|c|c|c|c|c|c|c|}
\hline Health indicators & $\begin{array}{c}\text { Very low } \\
\text { food security } \\
\text { (with hunger) }\end{array}$ & $\begin{array}{r}\text { Low } \\
\text { food security } \\
\text { (without } \\
\text { hunger) }\end{array}$ & Food Secure & Total & $\overline{x^{2}}$ & $\overline{\text { Df }}$ & $\begin{array}{r}P \\
\text { value }\end{array}$ \\
\hline \multicolumn{8}{|l|}{$\begin{array}{l}\text { Last hospital visits } \\
\text { by the elderly }\end{array}$} \\
\hline $\begin{array}{l}\text { Less than a week } \\
\text { ago }\end{array}$ & $0(0.0 \%)$ & $84(53.5 \%)$ & $73(46.5 \%)$ & $157(18.4 \%)$ & 184.822 & 6 & 0.000 \\
\hline $1-2$ weeks ago & $174(34.3 \%)$ & $160(31.6 \%)$ & $173(34.1 \%)$ & $507(59.4 \%)$ & & & \\
\hline $2-3$ weeks & $0(0.0 \%)$ & $18(81.8 \%)$ & $4(18.2 \%)$ & $22(2.6 \%)$ & & & \\
\hline Over 3 weeks & $0(0.0 \%)$ & $120(71.4 \%)$ & $48(28.6 \%)$ & $168(19.7 \%)$ & & & \\
\hline \multicolumn{8}{|l|}{$\begin{array}{l}\text { Common food } \\
\text { related illness of } \\
\text { the elderly in the } \\
\text { last } 12 \text { months }\end{array}$} \\
\hline Food poisoning & $174(42.2 \%)$ & $109(26.5 \%)$ & $129(31.3 \%)$ & $412(48.2 \%)$ & 277.948 & 8 & 0.000 \\
\hline Diarrhoea & $0(0.0 \%)$ & $60(56.6 \%)$ & $46(43.4 \%)$ & $106(12.4 \%)$ & & & \\
\hline Ulcer & $0(0.0 \%)$ & $24(96.0 \%)$ & $1(4.0 \%)$ & $25(2.9 \%)$ & & & \\
\hline Obesity & $0(0.0 \%)$ & $15(100.0 \%)$ & $0(0.0 \%)$ & $15(1.8 \%)$ & & & \\
\hline Indigestion & $0(0.0 \%)$ & $174(20.4 \%)$ & $122(14.3 \%)$ & $296(34.7 \%)$ & & & \\
\hline \multicolumn{8}{|l|}{$\begin{array}{l}\text { Vision of the } \\
\text { elderly }\end{array}$} \\
\hline Very good & $46(14.5 \%)$ & $129(40.6 \%)$ & $143(45.0)$ & $318(37.2 \%)$ & 56.838 & 6 & 0.000 \\
\hline Good & $65(30.4 \%)$ & $115(53.7 \%)$ & $34(15.9 \%)$ & $214(25.1 \%)$ & & & \\
\hline Fair & $62(19.5 \%)$ & $138(43.4 \%)$ & $118(37.1 \%)$ & $318(37.2 \%)$ & & & \\
\hline Poor & $1(25.0 \%)$ & $0(0.0 \%)$ & $3(75.0 \%)$ & $4(0.5 \%)$ & & & \\
\hline \multicolumn{8}{|l|}{$\begin{array}{l}\text { Ability of the } \\
\text { elderly to walk } \\
\text { without aid }\end{array}$} \\
\hline Very good & $14(22.6 \%)$ & $28(45.2 \%)$ & $20(32.2 \%)$ & $62(7.3 \%)$ & 72.164 & 6 & 0.000 \\
\hline Good & $14(9.0 \%)$ & $52(33.6 \%)$ & $89(57.4 \%)$ & $155(18.1 \%)$ & & & \\
\hline Fair & $65(30.7 \%)$ & $112(52.8 \%)$ & $35(16.5 \%)$ & $212(24.8 \%)$ & & & \\
\hline Poor & $81(19.1 \%)$ & $190(44.7 \%)$ & $154(36.2 \%)$ & $425(49.8 \%)$ & & & \\
\hline
\end{tabular}




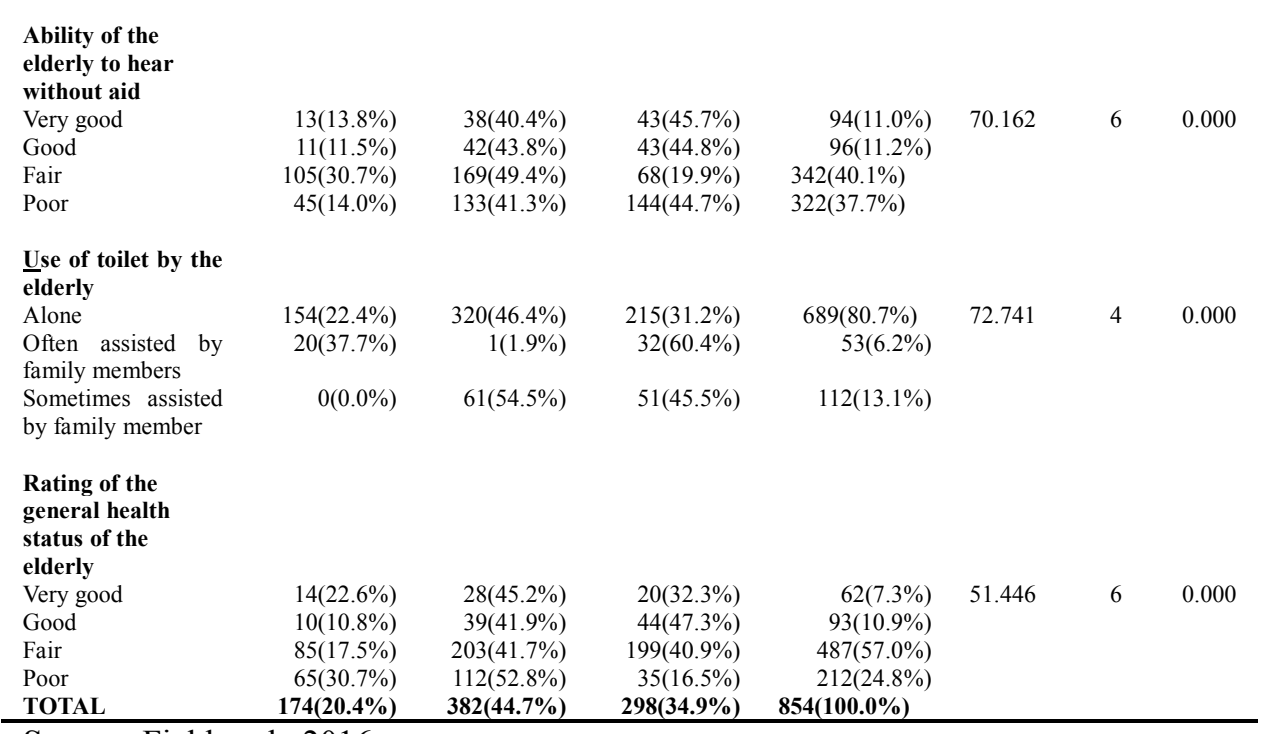

Source: Fieldwork, 2016

Table 4 shows that the self-rating of the indicators of health status of the elderly. The rate of hospitalisation was higher as most, $59.4 \%$ of the elderly visited hospitals between 1 to 2 weeks before the survey was carried out. The results showed that most, $77.8 \%$, of the respondents stated that elderly visited hospitals for treatment and medical check-up. This had implication on the general health status of the elderly as at the time of the study and as seen in the proportions of the respondents that were food insecure with hunger, $20.4 \%$ and without hunger, $28.5 \%$ amongst the elderly who visited hospitals. The table further reveals the most commonly reported food related illnesses of the elderly, twelve (12) months before the survey, was food contamination resulting in food poisoning identified by $48.2 \%$ respondents.

The study further examined the relationship between the means adopted by households to maintain and restore the health of the elderly and household food security as presented in table 5: 
Table 5: Relationship between Household Food Security and Production of Health

\begin{tabular}{|c|c|c|c|c|c|c|c|}
\hline $\begin{array}{l}\text { Household health } \\
\text { production practices }\end{array}$ & $\begin{array}{c}\text { Very low } \\
\text { food security } \\
\text { (with hunger) }\end{array}$ & $\begin{array}{r}\text { Low } \\
\text { food security } \\
\text { (without } \\
\text { hunger) }\end{array}$ & $\begin{array}{r}\text { Food } \\
\text { Secure }\end{array}$ & Total & $x^{2}$ & df & $\begin{array}{c}\text { P- } \\
\text { value }\end{array}$ \\
\hline \multicolumn{8}{|l|}{$\begin{array}{l}\text { Number of times the } \\
\text { elderly is fed before } \\
\text { normally }\end{array}$} \\
\hline Once daily & $120(85.7 \%)$ & $20(14.3 \%)$ & $0(0.0 \%)$ & $140(16.4 \%)$ & 676.316 & 6 & 0.000 \\
\hline Twice daily & $54(22.7 \%)$ & $143(60.1 \%)$ & $41(17.2 \%)$ & $238(27.9 \%)$ & & & \\
\hline Thrice daily & $(0.0 \%)$ & $214(58.3 \%)$ & $153(41.7 \%)$ & $367(43.0 \%)$ & & & \\
\hline $\begin{array}{l}\text { More than thrice } \\
\text { daily }\end{array}$ & $0(0.0 \%)$ & $5(4.6 \%)$ & $104(95.4 \%)$ & $109(12.8 \%)$ & & & \\
\hline \multicolumn{8}{|l|}{$\begin{array}{l}\text { Reasons for the } \\
\text { number of times the } \\
\text { elderly is fed } \\
\text { normally }\end{array}$} \\
\hline Customs and tradition & $116(28.2 \%)$ & $167(40.5 \%)$ & $129(31.3 \%)$ & $412(48.2 \%)$ & 63.768 & 8 & 0.000 \\
\hline Health status & $44(14.9 \%)$ & $130(43.9 \%)$ & $122(41.2 \%)$ & $296(34.7 \%)$ & & & \\
\hline Elderly's preference & $10(9.4 \%)$ & $50(47.2 \%)$ & $46(43.4 \%)$ & $106(12.4 \%)$ & & & \\
\hline Affordability & $4(16.0 \%)$ & $21(84.0 \%)$ & $0(0.0 \%)$ & $25(2.9 \%)$ & & & \\
\hline Availability & $0(0.0 \%)$ & $14(93.3 \%)$ & $1(6.7 \%)$ & $15(1.8 \%)$ & & & \\
\hline \multicolumn{8}{|l|}{$\begin{array}{l}\text { Number of times the } \\
\text { elderly is fed during } \\
\text { sickness }\end{array}$} \\
\hline Once daily & $0(0.0 \%)$ & $96(80.7 \%)$ & $23(19.3 \%)$ & $119(13.9 \%)$ & 323.455 & 6 & 0.000 \\
\hline Twice daily & $174(36.6 \%)$ & $143(30.1 \%)$ & $158(33.3 \%)$ & $475(55.6 \%)$ & & & \\
\hline Thrice daily & $0(0.0 \%)$ & $143(69.4 \%)$ & $63(306 \%)$ & $206(24.1 \%)$ & & & \\
\hline $\begin{array}{l}\text { More than thrice } \\
\text { daily }\end{array}$ & $0(0.0 \%)$ & $0(0.0 \%)$ & $54(100.0 \%)$ & $54(6.3 \%)$ & & & \\
\hline \multicolumn{8}{|l|}{$\begin{array}{l}\text { Reasons for the } \\
\text { number of times the } \\
\text { elderly is fed during } \\
\text { sickness }\end{array}$} \\
\hline $\begin{array}{l}\text { Advice by neighbour } \\
\text { and family }\end{array}$ & $0(0.0 \%)$ & $3(23.1 \%)$ & $10(76.9 \%)$ & $13(1.5 \%)$ & 499.810 & 10 & 0.000 \\
\hline Personal experience & $0(0.0 \%)$ & $113(74.8 \%)$ & $8(25.2 \%)$ & $151(17.7 \%)$ & & & \\
\hline $\begin{array}{l}\text { Lack of appetite by } \\
\text { the elderly }\end{array}$ & $174(42.2 \%)$ & $109(26.5 \%)$ & $129(31.3 \%)$ & $412(48.2 \%)$ & & & \\
\hline Medical advice & $0(0.0 \%)$ & $157(84.4 \%)$ & $29(15.6 \%)$ & $186(21.8 \%)$ & & & \\
\hline $\begin{array}{l}\text { Faith based/ } \\
\text { traditional healer }\end{array}$ & $0(0.0 \%)$ & $0(0.0 \%)$ & $61(100.0 \%)$ & $61(7.1 \%)$ & & & \\
\hline $\begin{array}{l}\text { Food belief and } \\
\text { tradition }\end{array}$ & $0(0.0 \%)$ & $0(0.0 \%)$ & $1(100.0 \%)$ & $31(3.6 \%)$ & & & \\
\hline \multicolumn{8}{|l|}{$\begin{array}{l}\text { Treatment pattern } \\
\text { of elderly when sick }\end{array}$} \\
\hline $\begin{array}{l}\text { Home with modern } \\
\text { drugs }\end{array}$ & $3(1.2 \%)$ & $173(68.4 \%)$ & $77(30.4 \%)$ & $253(29.6 \%)$ & 550.243 & 8 & 0.000 \\
\hline $\begin{array}{l}\text { Home with herbal } \\
\text { drugs }\end{array}$ & $171(53.4 \%)$ & $49(15.3 \%)$ & $100(31.3 \%)$ & $320(37.5 \%)$ & & & \\
\hline Public hospital & $0(0.0 \%)$ & $130(88.4 \%)$ & $17(11.6 \%)$ & $147(17.2 \%)$ & & & \\
\hline Private hospital & $0(0.0 \%)$ & $30(28.0 \%)$ & $77(72.0 \%)$ & $107(12.5 \%)$ & & & \\
\hline Faith based & $0(0.0 \%)$ & $0(0.0 \%)$ & $27(100.0 \%)$ & $27(3.2 \%)$ & & & \\
\hline \multicolumn{8}{|l|}{$\begin{array}{l}\text { Reasons for choice } \\
\text { of treatment pattern }\end{array}$} \\
\hline Affordability & $171(50.4 \%)$ & $68(20.1 \%)$ & $100(29.5 \%)$ & $339(39.7 \%)$ & 507.339 & 10 & 0.000 \\
\hline Accessibility & $3(1.3 \%)$ & $147(62.5 \%)$ & $85(36.2 \%)$ & $235(27.5 \%)$ & & & \\
\hline Perceived efficacy & $0(0.0 \%)$ & $106(93.8 \%)$ & $7(6.2 \%)$ & $113(13.2 \%)$ & & & \\
\hline Religion & $0(0.0 \%)$ & $25(92.6 \%)$ & $2(7.4 \%)$ & $27(3.2 \%)$ & & & \\
\hline Family preference & $0(0.0 \%)$ & $36(31.9 \%)$ & $77(68.1 \%)$ & $113(13.2 \%)$ & & & \\
\hline Choice by the elderly & $0(0.0 \%)$ & $0(0.0 \%)$ & $27(100.0 \%)$ & $27(3.2 \%)$ & & & \\
\hline
\end{tabular}




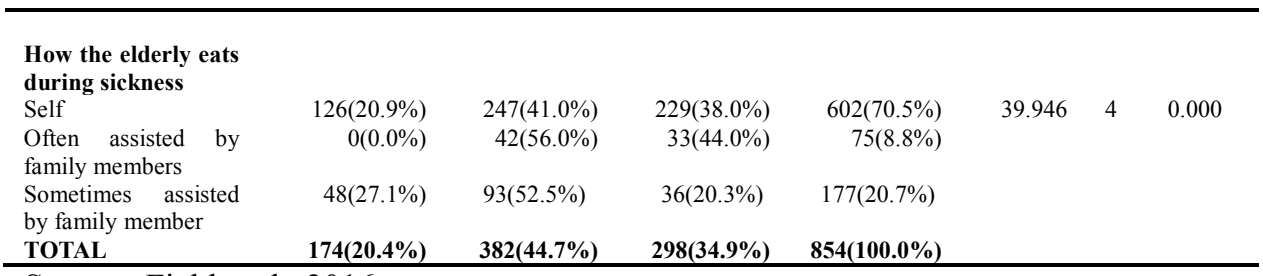

Source: Fieldwork, 2016

Table 5 presents health production as activities done in the households, in relation to feeding patterns and treatment choice, adopted to promote and sustain health of the elderly. The table reveals the relationship between the domains of food security and health of the elderly. Table 4 shows that majority, $70.9 \%$, of respondents fed the elderly between twice and thrice daily while only $16.4 \%$ fed the elderly once. The responses showed that customs and tradition influenced the choice of feeding patterns by most, $48.2 \%$, of the respondents, while only a total of $4.7 \%$ of the respondents considered affordability and availability of food in their choice number of times to feed the elderly.

On pattern of feeding the elderly during sickness, most, $55.6 \%$ respondents changed to feeding the elderly twice daily while only about $6.3 \%$ of the respondents adopted feeding more than thrice daily. Most, $48.2 \%$, respondents expressed lack of appetite by the elderly as reasons for their choice of feeding pattern, while some, $8.6 \%$, respondents claimed they were advised by traditional or faith based healers, neighbours and friends. Some, 3.6\% respondents based their food therapy decisions on food belief and traditions of the people.

\section{Relationship between household production of health and perceived health} status of the elderly

The study further examined the household health care practices in relation to the perceived effects of dietary behaviours on the health status of the elderly. This is presented in table 6 : 
Table 6: Household Production of Health and Perceived Health Status of the Elderly

\begin{tabular}{|c|c|c|c|c|c|c|c|}
\hline \multirow{2}{*}{$\begin{array}{l}\text { Household Health } \\
\text { Production practices }\end{array}$} & \multicolumn{3}{|c|}{ Perceived health status of the elderly } & \multirow[b]{2}{*}{ Total } & \multicolumn{3}{|c|}{ Chi-square test } \\
\hline & Very good & Good & Poor & & $\chi^{2}$ & df & $\begin{array}{c}\mathrm{P}- \\
\text { value }\end{array}$ \\
\hline \multicolumn{8}{|l|}{$\begin{array}{l}\text { Number of times the } \\
\text { elderly is fed before } \\
\text { sickness }\end{array}$} \\
\hline Once daily & $0(0.0 \%)$ & $0(0.0 \%)$ & $140(100.0 \%)$ & $140(16.4 \%)$ & 230.027 & 6 & 0.000 \\
\hline Twice daily & $2(0.8 \%)$ & $35(14.7 \%)$ & $201(84.5 \%)$ & $238(27.9 \%)$ & & & \\
\hline Thrice daily & $30(8.2 \%)$ & $185(50.4 \%)$ & $152(41.4 \%)$ & $367(43.0 \%)$ & & & \\
\hline More than thrice daily & $4(3.7 \%)$ & $60(55.0 \%)$ & $45(41.3 \%)$ & $109(12.8 \%)$ & & & \\
\hline \multicolumn{8}{|l|}{$\begin{array}{l}\text { Reasons for the } \\
\text { number of times the } \\
\text { elderly is fed before } \\
\text { sickness }\end{array}$} \\
\hline Customs and tradition & $30(7.3 \%)$ & $137(33.3 \%)$ & $245(59.5 \%)$ & $412(48.2 \%)$ & 109.436 & 8 & 0.000 \\
\hline Health status & $0(0.0 \%)$ & $60(20.3 \%)$ & $236(79.7 \%)$ & $296(34.7 \%)$ & & & \\
\hline Elderly's preference & $2(1.9 \%)$ & $58(54.7 \%)$ & $46(43.4 \%)$ & $106(12.4 \%)$ & & & \\
\hline Affordability & $4(16.0 \%)$ & $11(44.0 \%)$ & $10(40.0 \%)$ & $25(2.9 \%)$ & & & \\
\hline Availability & $0(0.0 \%)$ & $14(93.3 \%)$ & $1(6.7 \%)$ & $15(1.8 \%)$ & & & \\
\hline \multicolumn{8}{|l|}{$\begin{array}{l}\text { Number of times the } \\
\text { elderly is fed during } \\
\text { sickness }\end{array}$} \\
\hline Once daily & $3(2.5 \%)$ & $38(31.9 \%)$ & $78(65.6 \%)$ & $119(13.9 \%)$ & 154.976 & 6 & 0.000 \\
\hline Twice daily & $33(7.0 \%)$ & $222(46.7 \%)$ & $220(46.3 \%)$ & $475(55.6 \%)$ & & & \\
\hline Thrice daily & $0(0.0 \%)$ & $15(7.3 \%)$ & $191(92.7 \%)$ & $206(24.1 \%)$ & & & \\
\hline More than thrice daily & $0(0.0 \%)$ & $5(9.3 \%)$ & $49(90.7 \%)$ & $54(6.3 \%)$ & & & \\
\hline \multicolumn{8}{|l|}{$\begin{array}{l}\text { Reasons for the } \\
\text { number of times the } \\
\text { elderly is fed during } \\
\text { sickness }\end{array}$} \\
\hline $\begin{array}{l}\text { Advice by neighbour } \\
\text { and family }\end{array}$ & $0(0.0 \%)$ & $12(92.3 \%)$ & $1(7.7 \%)$ & $13(1.5 \%)$ & 171.878 & 10 & 0.000 \\
\hline Personal experience & $7(4.6 \%)$ & $60(39.7 \%)$ & $84(55.6 \%)$ & $151(17.7 \%)$ & & & \\
\hline $\begin{array}{l}\text { Lack of appetite by the } \\
\text { elderly }\end{array}$ & $29(7.0 \%)$ & $187(45.4 \%)$ & $196(47.6 \%)$ & $412(48.2 \%)$ & & & \\
\hline Medical advice & $0(0.0 \%)$ & $13(7.0 \%)$ & $173(93.0 \%)$ & $186(21.8 \%)$ & & & \\
\hline $\begin{array}{l}\text { Faith based/traditional } \\
\text { healer }\end{array}$ & $0(0.0 \%)$ & $5(8.2 \%)$ & $56(91.8 \%)$ & $61(7.1 \%)$ & & & \\
\hline Belief and tradition & $0(0.0 \%)$ & $3(9.7 \%)$ & $28(90.3 \%)$ & $31(3.6 \%)$ & & & \\
\hline \multicolumn{8}{|l|}{$\begin{array}{l}\text { Treatment pattern of } \\
\text { elderly when sick }\end{array}$} \\
\hline $\begin{array}{l}\text { Home with modern } \\
\text { drugs }\end{array}$ & $(5.9 \%)$ & $111(43.9 \%)$ & $127(50.2 \%)$ & $53(29.6 \%)$ & 158.725 & 8 & 0.000 \\
\hline Home with herbal drugs & $21(6.6 \%)$ & $148(46.2 \%)$ & $151(47.2 \%)$ & $320(37.5 \%)$ & & & \\
\hline Public hospital & $0(0.0 \%)$ & $8(5.4 \%)$ & $139(94.6 \%)$ & $147(17.2 \%)$ & & & \\
\hline Private hospital & $0(0.0 \%)$ & $11(10.3 \%)$ & $96(89.7 \%)$ & $107(12.5 \%)$ & & & \\
\hline Faith based & $0(0.0 \%)$ & $2(7.4 \%)$ & $25(92.6 \%)$ & $27(3.2 \%)$ & & & \\
\hline \multicolumn{8}{|l|}{$\begin{array}{l}\text { Reasons for choice of } \\
\text { treatment pattern }\end{array}$} \\
\hline Affordability & $20(5.9 \%)$ & $139(41.0 \%)$ & $180(53.1 \%)$ & $339(39.7 \%)$ & 163.994 & 10 & 0.000 \\
\hline Accessibility & $15(6.4 \%)$ & $121(51.5 \%)$ & $99(42.1 \%)$ & $235(27.5 \%)$ & & & \\
\hline Perceived efficacy & $1(0.9 \%)$ & $5(4.4 \%)$ & $107(94.7 \%)$ & $113(13.2 \%)$ & & & \\
\hline Religion & $0(0.0 \%)$ & $2(7.4 \%)$ & $25(92.6 \%)$ & $27(3.2 \%)$ & & & \\
\hline Family preference & $0(0.0 \%)$ & $11(9.7 \%)$ & $102(90.3 \%)$ & $113(13.2 \%)$ & & & \\
\hline Choice by the elderly & $0(0.0 \%)$ & $2(7.4 \%)$ & $25(92.6 \%)$ & $27(3.2 \%)$ & & & \\
\hline \multicolumn{8}{|l|}{$\begin{array}{l}\text { How the elderly eats } \\
\text { during sickness }\end{array}$} \\
\hline Self & $36(6.0 \%)$ & $249(41.4 \%)$ & $317(52.7 \%)$ & $602(70.5 \%)$ & 129.869 & 4 & 0.000 \\
\hline $\begin{array}{l}\text { Often assisted by family } \\
\text { members }\end{array}$ & $0(0.0 \%)$ & $29(38.7 \%)$ & $46(61.3 \%)$ & $75(8.8 \%)$ & & & \\
\hline $\begin{array}{l}\text { Sometimes assisted by } \\
\text { family member }\end{array}$ & $0(0.0 \%)$ & $2(1.1 \%)$ & $175(98.9 \%)$ & $177(20.7 \%)$ & & & \\
\hline TOTAL & $36(4.2 \%)$ & $280(32.8 \%)$ & $538(63.0 \%)$ & $854(100.0 \%)$ & & & \\
\hline
\end{tabular}

Source: Fieldwork, 2016 
Table 6 shows that most, $8.2 \%$, of the elderly who were feeding regularly, thrice daily, were perceived to have very good health whereas the frequency of feeding changed to twice daily by $50.4 \%$ respondents due largely the cost (affordability) of, and access to, required foods needed for their full recovery.

The study further analysed the multi-causal factors that determined the health status of the elderly. The study analysed the nature and strength of the relationship between the domains of food security, dietary behaviour and perceived health status of the elderly. This is presented in table 7:

Table 7: Multiple regression analysis of relationship between Food Security and Perceived Health Status of the Elderly

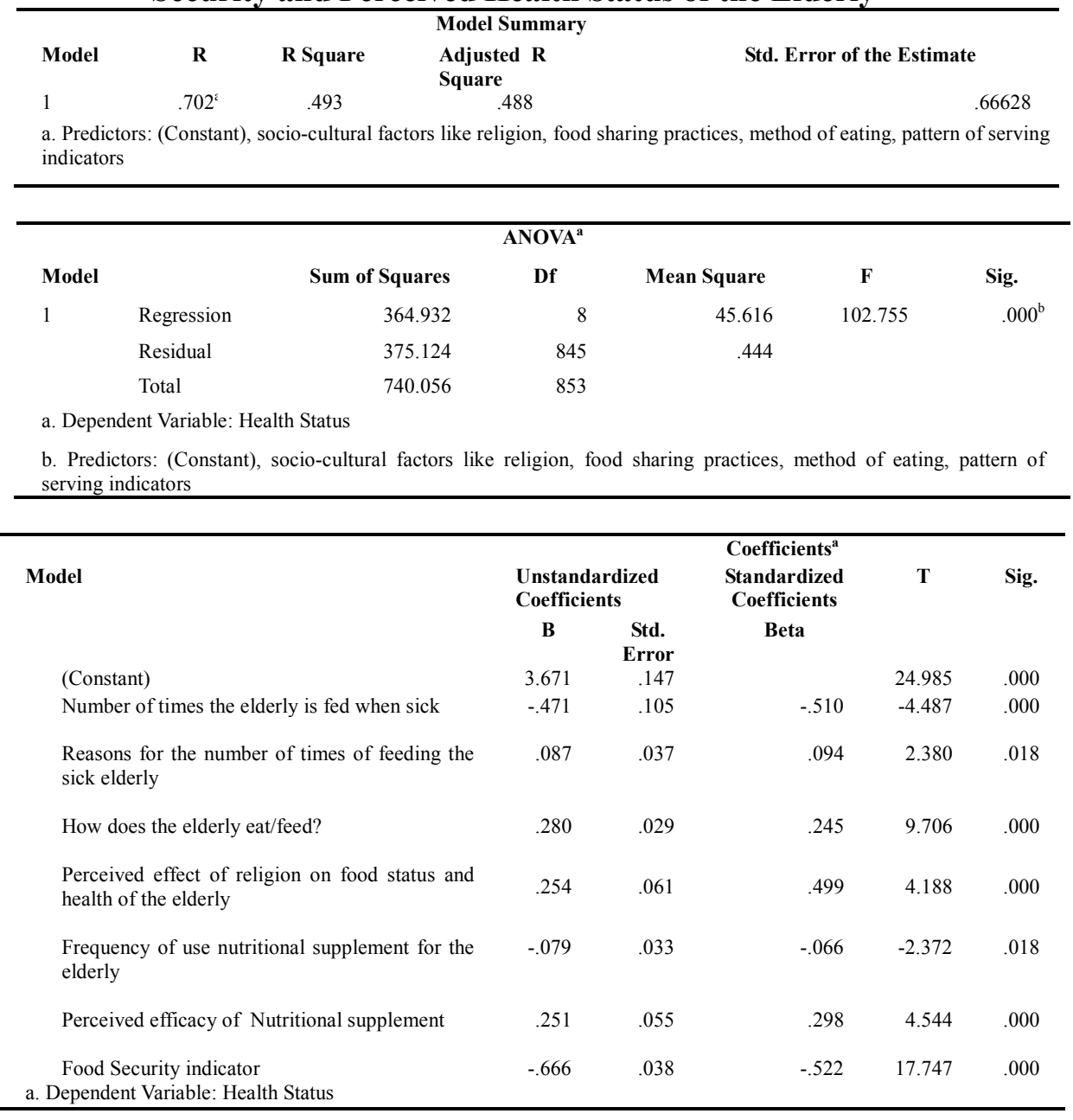

Table 7 shows that there was a significant relationship between household food security, household food culture and perceived health status of the elderly in the study area. Changes in feeding patterns, reasons for these changes, perceived effects of religion and use of nutritional supplements, and household 
food security indicators were found to further affect the health status of the elderly.

\section{Discussion of Findings}

Most households were headed by the elderly aged 60 and above, and who accounted for about $80 \%$ of respondents while only $20.4 \%$ of the respondents were below 60 years, and made up mostly of those taking care of their elderly parents and grandparents. Out of the respondents aged 60 and above, about $57 \%$, were aged $60-69$, the septuagenarians, aged $70-79$, were about $29 \%$ while about $14 \%$ were aged 80 and above. Thus most of the elderly in the study locations were sexagenarians who had just started to experience the challenges of ageing. This showed that respondents were capable of providing needed information for the study. The demographic characteristics of the respondents showed the patriarchal nature of the study area as an average Yoruba community with most, $89.3 \%$, of the households being male-headed. This confirmed previous work of Aidoo, Mensah and Tuffor (2013). The table also revealed the level of dependency as most of the elderly often required social and family support, with about $75 \%$ of the respondents married and living with their spouses, though some of the elderly were widowed and separated.

The demography of respondents confirmed the agrarian nature of the study area as majority $(36.0 \%)$ of the respondents earned a living from farming, while a few of the respondents, who were elderly aged 60 and above, were retirees who lived on pensions and family support. The results further showed that out of about $15 \%$ who earned above N40,000:00 only $2.3 \%$ earned above N60,000. This showed the limit of resources available at the disposal of the households for adequate feeding and healthcare of members, especially the dependent and vulnerable elderly. Family support and donations from friends and neighbours accounted for about $81 \%$ of other sources of income to the elderly in the households. Household income was found to significantly influence the Household Food Security status. This showed that the available food in the households for members to consume (access) depended largely on the inflow of cash (disposable income) required to purchase and produce food needed for healthy growth. This is in line with previous findings of Starr, McDonald and Bales (2015). Most elderly living alone lacked adequate social support while most living with other family members were found to be more food secured and of better health status. Elderly persons living alone are not likely to benefit from more resources pulled together and available to all members in large family, especially in food sharing as posited by National Institute of Ageing (NIA) (2011).

There were various dietary practices within the households which limited access by the elderly to safe and nutritious food for healthy ageing by the elderly. Findings showed that about $87 \%$ of the households often prepared same food for all members, including the elderly, while only about $5 \%$ cared to prepare separate food based on the preferences of the elderly. Some, 65(7.6\%) even sought other means of preparation of food for the elderly, such as buying 
already cooked or processed food from vendors, eateries and fast food joints. This showed that less attention was given to the needs or tastes of the elderly. The household heads and income earning members were served first, while only $6.3 \%$ of the respondents stated that the adults were always served first, irrespective how hungry the elderly might feel.

However, it was noted that the households where the elderly were served first were food secure. This revealed that care of the elderly is related to care of all other members of the household. And intra-household food sharing was largely according to status (about $48 \%$ ). Status was determined by physical and economic contribution of individuals to food production, which often was to the disadvantage of the dependent elderly. This is in line with findings by Perez- Escamilla, 2017 on the relations between healthy dietary habit and food security. However more (about 54\%) of the elderly served based on tradition were food secure. This showed the place of social acceptability of food as a determinant of food security status of household members.

The eating habits of households have changed as families have become more nucleated. About $96 \%$ households served their members separately while only about $4.4 \%$ of the respondents stated that all the elderly members ate together. This was not the feeding culture the elderly was used to and thus often lose appetite as a result of perceived lack of companionship. This made the food to be socially unacceptable, in line with the position of PerezEscamilla (2017) that food must not only be physically available but in socially acceptable ways to prevent nutritional vulnerability and negative healthy outcome. The results also revealed that the elderly were more food secure in households where members ate together (either based on gender or age) compared to only about $28 \%$ of those found to be in food secure households where members ate separately. To the elderly, manners of serving and eating food served a cultural value of uniting families in a traditional Yoruba household. Eating together symbolise unity amongst household member. This agrees with Weberian position on subjective meanings people attach to actions. On the determinants of food served to the elderly, the study established the bidirectional relationship between health status and food security status as about $69 \%$ of those hindered by health status from accessing adequate food were found in foods insecure households. It was also established that all $(100 \%)$ those limited by economic reasons (affordability) were found in low food secure (without hunger) households. This confirmed that the Socio-Economic Status of households and nutritional status are essentials to healthy ageing (Starr, McDonald and Bales, 2015; Research Triangle Institute (RTI) (2014).

About $48 \%$ of the respondents believed that the elderly could lose their appetite and thus become food insecure (without hunger) if they lack social support while only a few 45(6.3\%), respondents felt that lack of nutrition information could affect the food security status of the elderly. This underscores the importance of social support for the elderly. Most elderly were dependent on other members for their material needs. This position supports findings by Strickhouser, Wright, and Donley (2014). Also about $48 \%$ of the 
respondents also felt that religion determined the types of food that are served to the elderly. Religion determines household food culture in terms of prescription and proscription of certain foods for the elderly, and households are the locale for the expression of cultural values relating to food as noted by Lee (2017).

Further findings from the study revealed the health status of the elderly based on self-reported health conditions. The results revealed high rate of hospitalisation and food reported illness, especially food contamination. This showed that environmental factors and feeding habit played major roles in determining the food security and health status of the elderly. The results showed there was a significant relationship between the reported illnesses and household food security. This supports the position of Starr, McDonald and Bales (2015) that the three domains of Physiologic/Biomedical, Psycho/Social, and Environmental/Economic determine the breadth of potential causes of reduced dietary intake contributing to nutritional vulnerability in older adults.

Findings from the study further showed that the household heads adopted various strategies to restore and improve the health status of the elderly. Most elderly were normally fed twice to thrice daily but this was reduced to twice daily due largely the cost (affordability) of, and access to, required foods needed for their full recovery from sickness. Changes occurred in the feeding patterns adopted for the elderly largely due to several factors which were socioculturally situated. The influence of religion and culture on food therapy (proscription and prescription during sickness) was evident in the positions of respondents whose decisions were based on food belief and traditional feeding patterns of the people in line with the position of Lee (2017). This could have effects on the recovery rate of the elderly from sickness.

These results conform to the theoretical postulates that intrahousehold decisions on sharing of resources, including food, could be traditional action or value rational action, shaped by cultural and religious attachments. Mode of food storage, preparation of food and serving of food, food sharing and eating patterns determined the food security status of all members of the households surveyed. All these could affect the food habit of the elderly, increased their nutritional vulnerability and negatively impact on their health status, as observed by Olasunbo and Ayo (2013).

The field results showed there was little consideration for the preference of the elderly in choice of adopted dietary behaviours as means of aiding recovery from sicknesses. Food insecurity and food insufficiency (a closely related condition) have been shown to be associated with dietary behaviours of the households which influenced adherence to consumption of nutritious food, and thus exposed the elderly to higher risks of chronic diseases such as diabetes, hypertension, stroke and heart disease which can be prevented or treated by eating healthy food (Mudiare, 2013). Food insecurity was characterised by adoption of poor feeding patterns during sickness. This supports the findings of Gregorio, Rodriguess, Graca, de Sousa, Dias, Branco and Canhao (2018), that food insecurity is characterised by more health resource consumption and 
hospitalisation.

Further analysis of the results of the data from field, using ANOVA, showed that the health status of the elderly in the households surveyed depended largely on the household dietary behaviour, as it affects the household food security status, and the activities by the household heads and members towards promoting, restoring and maintaining their health, including that of the elderly. It thus confirms the household dietary behaviour as critical in shaping the household as primary source of meeting the food and health needs of the elderly. This further reinforces Research Triangle Institute, RTI (2014), position that increased stress arising from food insecurity also contributes to poor physical and mental health outcomes in the elderly. There are multiple stresses resulting from changing dietary behaviour towards managing chronic health conditions, especially adhering strictly to recommended feeding patterns, in the face of food insecurity in line with the observation of Perez-Escamilla (2017).

\section{Conclusion}

The study concludes that there was a significant relationship between various dietary behaviours of the households and access to safe and nutritious food. This influenced the outcome of all efforts towards restoring the health status of the elderly. The study also showed the bi-directional relationship between food and health. It confirmed that Healthy Dietary Behaviour in the form of feeding patterns before and after sickness may help in diseases' prevention or accelerate recovery rate of the elderly from sickness. The study provides strong evidence that food insecurity is a social and public health issue which strongly associates with the dietary behaviours of the households. It further revealed that healthy dietary behaviour is significant to determine the health status of the elderly.

\section{Recommendations}

Society should avoid discriminatory dietary behaviour in household food sharing which may limit access by the elderly to food and health care. There is need to further examine the impact of household social dynamics on food security and health, especially as it relates to access by the elderly to adequate and nutritious food for healthy ageing.

\section{Limitation}

The study was based largely on behavioural assessment of determinants of impacts of food security on health. The study focused on the individual selfrating of health status. Respondents were household heads, a few of who were not elderly but caregivers. Measuring health outcomes was not based on any clinical evaluation but social model of health. The study captured largely social components of health in terms of health related issues that provided relevant information about the consequences of HDB and food security. 


\section{References}

Aidoo, R., Mesah, J.O. and Tuffour, T. (2013) Determinants of Household Food Security in the Sekyere- Afam Plants District Ghana. 1st Annual International Interdisciplinary Conference, AIIC 2013, 24-26 April, Azores, Portugal - Proceedings. Retrieved on September 20, 2015.

Ekot, M.O. (2013) Food Insecurity among the elderly in Akwa Ibom State. FUTA J. Res. Sci., 9(1): 25-33.

FAO, IFAD, UNICEF, WFP and WHO (2017) The State of Food Security and Nutrition in the World 2017. Building resilience for peace and food security, Rome, FAO.

Gholami, A., Rezaei, S.T., Askari, M., Moosavi, J., Dehghan, A. (2013) Food insecurity status and associated factors among rural households in North-East of Iran. Int J Prev Med 2013, 4: 1018-24.

Gregorio, M.J., Rodriguess, A.M., Graca, P., de Sousa, R.D., Dias, S.S., Branco, J.C. and Canhao, H. (2018) Food Insecurity is Associated with Low Adherence to the Mediterranean Diet and Adverse Health Conditions in Portuguese Adults. Front. Public Health. 6: 38.

Group, E. 2016. How culture and Society Influence Healthy Eating. Global Healing Center. Accessed on 2nd June, 2018 from www.globalhealingcenter.com.

Gurung, S. and Ghimire, S. (2014) Role of family in Elderly care: Bachelor Thesis, School of Health Care and Social Services. Degree of Nursing, Lapland University of Applied Sciences.

Hossain, F. and Ali, M. (2014) Relation between individual and Society. Open Journal of Social Sciences. 02: 130-137. doi:10.4236/jss.2014.28019.

Läidmäe, V., Tammsaar, K., Tulva, T. and Kasepalu (2012) Quality of Life of Elderly in Estonia. The Internet Journal of Geriatrics and Gerontology. 7(1), http://ispub.com/IJGG/7/1/14023.

Lake, I., Hooper, L., Abdelhamid, A., Bemtham, G., Boxali, A.B., Draper, A., Fairwether-Tait, S., Hulme, M., Hunter, P.R., Nichols, G. and Waldron, K. (2012) Climate Change and Food Security; Health impacts in developed countries. Environmental Health Perspective, 120(11).

Lee, R.L.M. (2017) Malaysian Identities and Melange Food Cultures. Journal of Intercultural Studies, 38(2).

Mudiare, P.E.U. (2013) Abuse of the Aged in Nigeria: Elders Also Cry. American International Journal of Contemporary Research, 3(9): 79-87.

National Institute of Ageing (NIA) (2011) Global Health and Aging. National Institute of Ageing. National Institute of Health. NIH Publication no.117737.

Olasunbo, O.I. and Ayo, D.S. (2013) Health Seeking Behaviour, Food Habit and Nutritional Assessment of an Elderly Group in Ile Ife, Nigeria. $J$ Community Med Health Educ. 3(5), http://dx.doi.org/10.4172/2161.

Perez-Escamilla, R. (2017) Food security and the 2015 -2030 Sustainable Development Goals: From Human to Planetary Health: Perspectives and Opinions - Current Development in Nutrition, 1(7). 
Research Triangle Institute (RTI) (2014) Current and Prospective Scope of Hunger and Food Security in America: A Review of Current Research. RTI International Center for Health and Environmental Modelling 3040 E. Cornwallis Road Research Triangle Park, NC 27709-2194.

Riang'a, R.M., Broerse, J. and Nangulu, A.K. (2017) Food beliefs and practices among the Kalenjin pregnant women in rural Uasin Gishu County, Kenya. J Ethnobiol Ethnomed, 13(29).

Starr, K.N., Porter, McDonald, S.R. and Bales, C.W. (2015) Nutritional Vulnerability in Older Adults: A Continuum of Concerns. Curr Nutr Rep. Jun; 4(2): 176-184.

Strickhouser, S., Wright, J. D. and Donley, A.M. (2014) Food Insecurity among Older Adults. A Report Submitted to AARP Foundation 601 E Street, NW, Washington, DC 20049. www.aarpfoundation.org. 